\title{
Validitas dan Realibilitas Instrumen Teori Pilihan Karir Holland di Indonesia
}

\author{
Weni Anggraini ${ }^{1 *}$, Fandy Kurniawan², (D) Susilawati Susilawati ${ }^{3}$, \\ Afra Hasna ${ }^{4}$ \\ Universitas Negeri Semarang, Indonesia ${ }^{1}$ \\ Sekolah Menengah Pertama Negeri 1 Ungaran, Indonesia ${ }^{2}$ \\ Universitas Bengkulu, Indonesia ${ }^{3}$ \\ Universitas Riau, Indonesia ${ }^{4}$ \\ @weniang26@gmail.com*
}

Submitted:
2020-06-19
Revised:
2020-08-31
Accepted:
2020-10-02
Copyright holder:
(C) Anggraini, W., Kurniawan, F., Susilawati, S., \& Hasna, A.
(2020)
This article is under:
CC C
How to cite:
Anggraini, W., Kurniawan, F., Susilawati, S., \& Hasna, A.
(2020). Validitas dan Realibilitas Instrumen Teori Pilihan Karir
Holland di Indonesia. Bulletin of Counseling and
Psychotherapy, 2(2).
Published by:
Kuras Institute
Journal website:
https://journal.kurasinstitute.com/index.php/bocp
E-ISSN:
2656-1050

\begin{abstract}
Validity and reliability are the main topics in every research instruments. It is important how to create research instrument that is connected to the construct being measured. In this article, the authors tested the validity and reliability of Holland's career instrument Indonesian version. The participants involved are in the period of career preparation and choice, within an educational institution or a job, but has not yet had satisfaction with their career. The participants' age range from 15 to 27 years. The validity test is carried out using the conventional validity type, where the item is declared valid if the correlation coefficient is $\geq$ 0.3. The results showed 43 items were declared valid and 5 items were declared invalid while the reliability coefficient found is 0.906. Based on the results, Holland's career instrument Indonesian version in a good instrument to measure career preparation and career choice.
\end{abstract}

KEYWORDS: career choice; career preparation; holand's career scale

\section{PENDAHULUAN}

Karir adalah hal yang sangat penting bagi setiap individu dalam menjalani kehidupannya, karena karir adalah bagian dari identitas seseorang. Penting bagi seseorang dalam menentukan pilihan karir yang akan yang tepat yang akan ditekuninya dalam kehidupan sehari-hari (Holie, 2000). Kematangan karier merupakan aspek yang perlu dimiliki siswa untuk menunjang karier dimasa depan lebih lanjut karir juga memiliki hubungan positif yang sangat signifikan dengan motivasi belajar siswa (Wijaya, 2012). Mengingat pentingnya kematangan karir siswa maka sudah seharusnya layanan konseling memiliki alat ukur minat dan karir yang memadai.

Asesmen minat karir berguna dalam mempermudah proses pengambilan keputusan karir (Gati \& Peretz, 2011). Sedangkan Cummings \& Worley (2009) juga memperkuat bahwa proses diagnosa awal terhadap minat karir individu perlu untuk dilakukan sebagai upaya awal pada proses intervensi dan juga pengembangan karir. Maka penting bagi konselor sekolah memiliki alat asesmen yang memiliki nilai validitas dan realibilitas yang baik guna mempermudah dalam mengungkap kebutuhan siswa.

Validitas dan reliabilitas menjadi bahasan utama dalam setiap pengukuran dalam penelitian. Keduanya berfokus bagaimana menciptakan pengukuran yang terhubung dengan konstruk yang diukur. Reliabilitas dan validitas menjadi hal yang sangat penting karena konstruk pada teori sosial seringkali ambigu, membingungkan dan sering kali tidak dapat secara langsung teramati. Semua peneliti sosial ingin pengukuran yang mereka lakukan memiliki validitas dan reliabilitas yang baik. 
Validitas berasal dari kata validity yang berarti sejauhmana ketepatan dan kecermatan pengukur (tes) dalam melakukan fungsi ukurnya (Azwar, 2011). Sudjana (2004, dalam Widodo, 2006) menyatakan bahwa validitas berkenaan dengan ketepatan alat penilaian terhadap konsep yang dinilai sehingga betul-betul menilai apa yang seharusnya dinilai. Reliabilitas berarti keandalan atau konsistensi. Hal ini menunjukkan bahwa pengukuran atribut yang sama diulang akan memberikan hasil kondisi yang identik atau sangat mirip. Reliabilitas dalam penelitian kuantitatif menunjukkan bahwa hasil numerik yang dihasilkan oleh suatu indikator tidak berbeda karena karakteristik dari proses pengukuran atau instrumen pengukuran itu sendiri. Kebalikan dari reliabilitas adalah pengukuran yang memberikan hasil yang tidak menentu, tidak stabil, atau tidak konsisten (Neuman, 2007).

Validitas digunakan sebagai pengembangan dan pengevaluasian suatu tes. Selain itu, validitas juga diperlukan untuk mengetahui kelayakan butir-butir dalam suatu konstruk pertanyaan dalam mendefinisikan suatu variabel reliabilitas digunakan sebagai indikator dalam mempercayai nilai dari suatu tes karena memiliki konsistensi (Jacobs, 1991). Suatu tes dapat dikatakan memiliki validitas yang tinggi jika tes tersebut menjalankan fungsi ukurnya, atau memberikan hasil ukur yang tepat dan akurat sesuai dengan maksud dikenakannya tes tersebut. Suatu tes menghasilkan data yang tidak relevan dengan tujuan diadakannya pengukuran dikatakan sebagai tes yang memiliki validitas rendah. Sehingga pelaksanaan validitas dan reliabilitas suatu tes bersifat sangat penting.

Hal ini didukung oleh pernyatan Suryabrata, 2000; Djaali, 2000) yang menyatakan bahwa validitas suatu tes pada dasarnya merujuk pada derajat fungsi pengukuran suatu tes, atau derajat kecermatan ukuran sesuatu tes, serta konsistensi butir pernyataan pada tes apabila dilakukan pengujian pada kelompok yang sama di waktu yang berbeda selalu memberikan hasil yang sama. Penelitian terdahulu juga mengungkapkan untuk dapat melalukan validasi ulang sehingga dapat diperoleh validitas konstruk sesuai dengan konstruk tipologi minat karir menurut Holland (Ratri, 2016). Penelitian yang dilakukan di Kroasia mengungkapkan bahwa intrumen Holland yang di ujikan kepada 1866 remaja di Kroesia instrumen dinilai baik dan handal untuk digunakan (Sverko \& Babarovic, 2006). Penelitian lain yang dilakukan di Brazil menguji instrument Holland yang dengan jumlah responden sebanyak 1256 pelajar SMA mengungkapkan bahwa enam factor RIASEC pada instrument Holland bersifat konsisten (Maireles \& Primi, 2015). Namun penelitian yang dilakukan di Hong Kong mengungkapkan bahwa ada beberapa faktor kontekstual budaya yang mungkin berhubungan dengan kurangnya kesesuaian model Holland dalam sampel Hong Kong (Farh, Leong \& Law 1998). Maka dalam penelitian ini akan mengukur kembali validitas dan realibilitas terhadap instrument minat karir Holland di wiliayah Indonesia, hal ini sebagai upaya untuk mengetahui keakuratan instrumen Holland dalam penerapan di Indonesia.

\section{Kajian Pustaka}

Teori pilihan karir yang dikembangkan oleh John L. Holland adalah teori pengembangan karier yang paling banyak diterapkan baik dalam penentuan karir seseorang. Kepribadian seseorang biasanya mencerminkan terhadap pilihan karir yang akan dijalaninya. Beberapa teori menggabungkan beberapa konstruksi terhadap psikologi kepribadian, yang diantaranya perilaku kejuruan, dan psikologi sosial, termasuk teori persepsi diri dan stereotip sosial (Foutch, McHugh, Bertoch, \& Reardon, 2014). Penerapan teori pilihan karir Holland melibatkan penilaian individu dalam beberapa tipe kepribadian yang menonjol pada individu yang kemudian dicocokkan sesuai dengan tipe individu dan juga aspek lingkungan. Teori Holland juga memprediksi bahwa semakin akurat kesesuaian antara karakteristik individu dan pekerjaan atau pilihan kair seseorang maka semaikin memberikan pengaruh yang potensi terhadap keberlangsungan karir, serta mempengaruhi kepuasan, kegigihan, dan prestasi seseorang (Lent, Sheu, \& Brown, 2010).

Teori Holland telah memberikan pengaruh yang penting dalam pemilihan karir baik di Amerika Serikat maupun dalam kanca internasional. Holland mendalilkan bahwa minat vokasional adalah ekspresi kepribadian seseorang, dan bahwa kepentingan kejuruan dapat dikonseptualisasikan 
kedalam enam tipologi (RIASEC) yang diantaranya Realistis, Investigasi, Artistik, Sosial, Enterprising, dan Konvensional (Leung, 2008). John Holland (RIASEC) menyatakan bahwa dalam memilih karir, orang lebih suka pekerjaan dimana mereka bisa berada di sekitar orang lain yang memiliki minat dan tipe kepribadian yang seperti mereka, lebih lanjut mereka juga akan memilih lingkungan yang dapat memfasilitasi mereka dalam mengeksprsikan diri dan kemampuannya (Hurtado Rúa, Stead, \& Poklar, 2019; McKay \& Tokar, 2012, Sheu, et al., 2010).

Namun ada hal yang juga harus diperhatikan dalam teori Holland yang diantaranya adalah kekuatan dan juga kelemahan. Adapun kelebihan dari teori Holland dinilai sebagai teori yang bersifat komperhensif yang menjangkau pola hidup individu dan sebagai teori yang mendapatkan banyak dukungan dari hasil penelitian (Winkel \& Hastuti, 2005). Hal yang lain yang menjadi kekuatan dari teori ini yaitu mengenai penggabungan beberapa konstruksi dari psikologi kepribadian, perilaku vokasional, dan psikologi sosial, termasuk teori persepsi diri dan stereotip sosial (Greenhaus \& Callanan, 2006). Sedangkan kekurangan pada teori Holland mengenai tahap-tahap atau tingkat yang dapat dicapai oleh seseorang dalam bidang okupasi tertentu, Holland menunjuk pada taraf intelegensi yang memungkinkan tingkat pendidikan sekolah tertent, namun dipertanyakan apakah masih ada faktor-faktor lainnya (Winkel \& Hastuti, 2005).

\section{METODE PENELITIAN}

Instrumen yang diukur tingkat validitas dan reliabilitasnya adalah Holland Code Test dari personality-testing info courtesy Interest Item Pool (IPP). Skala ini diadobsi dari pemilik teori dengan menggunakan prosedur dan pedoman yang disesuaikan dengan proses adabtasi skala dalam penilaian konseling yang meliputi tahapan forward translation, translation review, back translate, expert judgment, prestesting dan revision (Lenz et al, 2017).

Dimana dalam pelaksanaan pengukuran validitas dan reliabiltas skala responden yang dibutuhkan adalah mereka dengan kriteria rentang usia berada pada usia 15-27 tahun yang berada pada suatu institusi pendidikan ataupun mereka bekerja namun belum memiliki kepuasan karir dan yang sedang memilih dan mempersiapkan karir. Responden untuk uji validitas dan reliabilitas skala ini disebar di Indonesia. Yang diharapkan mampu memberikan berbagai pandangan dan kepribadian yang disesuaikan dengan kebudayaan. Jumlah responden adalah 220 orang yang terdiri dari 77 lakilaki dan 143 perempuan. Kemudian terdiri dari 152 orang berasal dari perguruan tinggi, 48 orang dari sekolah menengah atas.

Pengolahan data dilakukan dengan bantuan aplikasi Statistic Package for Social Science (SPSS). Untuk mendapatkan validitas menggunakan analisis perason correlation dan reliabilitas menggunakan analisis reliability.

\section{HASIL DAN PEMBAHASAN}

Validitas dilakukan dengan menggunakan jenis validitas konvensional. Dimana validitas ini merupakan validitas yang mendemonstrasikan skor tes berkolaborasi secara sistemik dengan skor total. Semakin mendekati angka 1 maka tes itu semakin valid. Serta batas minimumnya adalah $\geq 0,3$. Jika koefisien korelasinya $\geq 0,3$ maka item tersebut dikatakan valid. Hasil dari pelaksanaan validitas instrumen karir Holland dapat diketahui pada tabel 1.

\begin{tabular}{lllllll}
\hline Item & Pearson Correlation & Ket & & Item & Pearson Correlation & Ket \\
\cline { 1 - 2 } \cline { 5 - 6 } Item 1 & 0,281 & Tidak Valid & & Item 25 & 0,514 & Valid \\
Item 2 & 0,256 & Tidak Valid & & Item 26 & 0,516 & Valid \\
Item 3 & 0,390 & Valid & & Item 27 & 0,464 & Valid \\
Item 4 & 0,296 & Tidak Valid & & Item 28 & 0,240 & Tidak Valid \\
Item 5 & 0,350 & Valid & & Item 29 & 0,568 & Valid \\
Item 6 & 0,238 & Valid & & Item 30 & 0,377 & Valid \\
\hline
\end{tabular}




\begin{tabular}{|c|c|c|c|c|c|}
\hline Item 7 & 0,446 & Valid & Item 31 & 0,412 & Valid \\
\hline Item 8 & 0,355 & Valid & Item 32 & 0,483 & Valid \\
\hline Item 9 & 0,407 & Valid & Item 33 & 0,476 & Valid \\
\hline Item 10 & 0,373 & Valid & Item 34 & 0,462 & Valid \\
\hline Item 11 & 0,459 & Valid & Item 35 & 0,490 & Valid \\
\hline Item 12 & 0,180 & Tidak Valid & Item 36 & 0,342 & Valid \\
\hline Item 13 & 0,392 & Valid & Item 37 & 0,519 & Valid \\
\hline Item 14 & 0,469 & Valid & Item 38 & 0,455 & Valid \\
\hline Item 15 & 0,493 & Valid & Item 39 & 0,452 & Valid \\
\hline Item 16 & 0,494 & Valid & Item 40 & 0,413 & Valid \\
\hline Item 17 & 0,610 & Valid & Item 41 & 0,315 & Valid \\
\hline Item 18 & 0,517 & Valid & Item 42 & 0,499 & Valid \\
\hline Item 19 & 0,388 & Valid & Item 43 & 0,533 & Valid \\
\hline Item 20 & 0,501 & Valid & Item 44 & 0,570 & Valid \\
\hline Item 21 & 0,481 & Valid & Item 45 & 0,494 & Valid \\
\hline Item 22 & 0,335 & Valid & Item 46 & 0,342 & Valid \\
\hline Item 23 & 0,312 & Valid & Item 47 & 0,498 & Valid \\
\hline Item 24 & 0,567 & Valid & Item 48 & 0,494 & Valid \\
\hline
\end{tabular}

Tabel 1. Hasil validitas instrumen karir Holland

Berdasarkan hasil olah data menggunakan SPSS 20. dapat diketahui bahwa dari 48 item instrumen yang valid berjumlah 43 item dan tidak valid 5 item. Item yang tidak valid adalah item 1, 2, 4, 12 dan 28. Sedangkan item yang valid adalah item $3,5,6,7,8,910,11,13,14,15,16,17,18,19$, $20,21,22,23,24,25,26,27,29,30,31,32,33,34,35,36,37,38,39,40,41,42,43,44,45,46,47$, dan 48.

Purwanto (2016) menyatakan bahwa reliabilitas didefinisikan sebagai tingkat sejauh mana skor tes konsisten, dapat dipercaya, dan dapat diulang. Untuk mengetahui tingkat reliabilitas suatu tes maka dilihat koefisien reliabilitas. Koefisien reliabilitas bergerak dari 0,00 sampai dengan 1,00. Tes yang reliabel adalah yang mendekati 1,00 . Hasil dari olah data reliabilitas instrumen karir Holland dapat diketahui bahwa nilai koefisien reliabilitasnya adalah 0,906. Sehingga dapat disimpulkan bahwa instrumen karir Holland bersifat reliabel dengan kriteria sangat bagus. Hal ini dapat dilihat pada tabel 2.

$\frac{\frac{\text { Cronbach's Alpha } \quad \mathrm{N} \text { of Items }}{0,906} 48}{\text { Tabel 2. Reliabilitas instrumen karir Holland }}$

Validitas dan reliabilitas suatu instrumen merupakan hal yang sangat penting dalam pelaksanaan penelitian. Valid dan reliabel suatu instrumen akan menentukan keberhasilan dari sebuah penelitian. Pelaksanaan validitas pada instrumen ini menggunakan validitas kriteria. Pelaksanaan validasi dan reliabilitas dilakukan kepada 220 responden yang tersebar dari Sabang sampai Merauke. Hasil dari validasi instrumen dapat diketahui bahwa dari 48 item instrumen terdapat 5 item yang tidak valid dan 43 item yang valid. Dan hasil reliabilitasnya adalah sangat bagus dengan nilai 0,906 .

Hasil penelitian mengungkapkan di Indonesia memiliki tingkat validitas dan reliabilitas yang baik dan ini sejalan dengan penelitian sebelumnya yang dilakukan di Kroasia dengan jumlah responden sebanyak 1588 siswa mengungkapkan bahawa intrumen Holland ini memiliki tingkat validitas dan realibilitas yang baik (Sverko \& Babarovic, 2006) dan hal itu sejalan dengan penelitian yang dilakukan di Brazil dengan jumlah responden sebanyak 1265 SMA mengungkapkan bahwa enam 
faktor RIASEC pada instrumen Holland bersifat konsisten (Maireles \& Primi, 2015). Namun dalam penelitian ini juga mengalami kelemahan dimana jumlah responden yang dinilai masih belum kuat sehingga dalam penelitian selanjutnya dapat mempertimbangkan jumlah responden.

\section{KESIMPULAN DAN SARAN}

Karir adalah hal yang sangat penting bagi seseorang individu dalam menjalani kehidupannya sehati-hari, kepribadian juga menceriminkan pilihan karir yang dimiliki seseorang, lebih dari itu orang yang memiliki tipe yang sama akan menciptakan suatu lingkungan yang dapat memfasilitasi perkembangannya. Melihat karir begitu pentingnya bagi seorang individu maka sudah seharusnya konselor memiliki alat ukur pilihan karir yang dinilai akurat dalam mengukur karir individu, maka dalam penelitian ini melakukan uji validitas dan realibilitas terhadap instrument teori karir Holland.

Validitas dari instrument ini dinilai baik namun ada beberapa item yang dinyatakan tidak valid dan nilai reliabelitas yang tinggi sehingga dalam studi selanjutnya instrument ini dapat digunakan namun harus memperhatikan dan memodifikasi beberapa item yang dinilai tidak valid dengan mencocokan dengan kondisi lingkungan dan budaya yang sesuai dengan lokasi penelitian selanjutnya selain itu jika ingin menguji kembali tingkat validitas dan reliabilitas dapat dengan mempertimbangakan jumlah responden dengan skala yang lebih besar.

\section{DAFTAR PUSTAKA}

Azwar, S. (2011). Tes Prestasi: Fungsi dan pengembangan pengukuran prestasi belajar. Yogyakarta: Pustaka Pelajar.

Cummings, T.G \& Worley, C.G. (2009). Organization Development \& Change, 9th edition. USA: Cengage Learning

Djaali., dkk. 2000. Pengukuran Dalam Pendidikan. Jakarta: Program Pascasarjana.

Farh, Jiing-lih., Leong, Frederick T, L., \& Law, Kenneth S. (1998). Cross-Cultural Validity of Holland's Model in Hong Kong. Journal Of Vocational Behavior 52, 425- 440 https://doi.org/10.1006/jvbe.1997.1631

Foutch, H., McHugh, E. R., Bertoch, S. C., \& Reardon, R. C. (2014). Creating and using a database on Holland's theory and practical tools. Journal of Career Assessment, 22(1), 188-202 https://doi.org/10.1177\%2F1069072713492947

Gati, I \& Peretz, L.A. (2011). Internet-Based Self-Help Career Assessments and Interventions: Challenges and Implications for Evidence-Based Career Counseling. Journal of Career Assessment August 2011 vol. 19 no. 3 259-273. https://doi.org/10.1177/1069072710395533

Hoile, P.C. (2000). Improving Person-Environment Fit: Increasing Job Satisfaction by Matcing Employees Preferred Levels of Arousal to Job Complexity Within Holland's Model of Occupational Types. Desertasi. USA: Bell \& Howell Information and Learning Company

Holland Code Test dari personality-testing info courtesy Interest Item Pool (IPP). Retrieved from Google Scholar

Hurtado Rúa, S. M., Stead, G. B., \& Poklar, A. E. (2019). Five-Factor Personality Traits and RIASEC Interest Types: A Multivariate Meta-Analysis. Journal of Career Assessment, 27(3), 527-543. https://psycnet.apa.org/doi/10.1177/1069072718780447

Lent, R. W., Sheu, H.-B., \& Brown, S. D. (2010). The self-efficacy-interest relationship and RIASEC type: Which is figure and which is ground? Comment on Armstrong and Vogel (2009). Journal of Counseling Psychology, 57(2), 219-225. https://doi.org/10.1037/a0019039

Lenz, A.S., Soler, I. G., Dell'Aquilla, J., \& uribe, P.M. (2017). Translation and cross cultural adaptation of assessments for use in counseling research. Measurement and Evaluastion in Counseling and Development, 50(4), 224-231. http://doi.org/10.1080/07481756.2017.1320947

Leung, S. A. (2008). The big five career theories International handbook of career guidance (pp. 115132): Springer. 
McKay, D. A., \& Tokar, D. M. (2012). The HEXACO and five-factor models of personality in relation to RIASEC vocational interests. Journal of Vocational Behavior, 81(2), 138-149. https://psycnet.apa.org/doi/10.1016/j.jvb.2012.05.006

Meireles, E., Primi, R. (2015) Validity and Reliability Evidence for Assessing Holland's Career Types. Journal of Paideia 25(62), 307-315. http://dx.doi.org/10.1590/1982-43272562201504

Neuman, W. L. (2007). Basic of social research: Qualitative and quantitative qpproaches, second edition. Pearson Education, Inc.

Purwanto, Edi. 2016. Metodologi Penelitian Kuantitatif. Yogyakarta: Pustaka Pelajar.

Ratri, Widiasih Diana (2016). Validasi Holland Self Directed Search (Sds) Form Cp Sebagai Alat Ukur Minat Karir. Naskah Publikasi: Program Magister Psikologi Profesi Fakultas Psikologi Universitas Gadjah Mada Yogyakarta. https://www.academia.Edu/34601886/

Sheu, H.-B., Lent, R. W., Brown, S. D., Miller, M. J., Hennessy, K. D., \& Duffy, R. D. (2010). Testing the choice model of social cognitive careertheory across Holland themes: A meta-analytic path analysis. Journal of Vocational Behavior, 76(2), 252-264. https://doi.org/10.1016/j.jvb.2009.10.015

Suryabrata, Sumadi. 2000. Pengembangan Alat Ukur Psikologis. Yogyakarta: Andi.

Sverko, I., Babarovic, T. (2006) The Validity of Holland's Theory in Croatia. Journal of Career Assessment. 14(4), 409-507. https://doi.org/10.1177/1069072706288940

Widodo, P. B. (2006). Reliabilitas dan validitas konstruk skala konsep diri untuk mahasiswa Indonesia. Jurnal Psikologi Universitas Diponegoro, 3 (1), 1-9.

Wijaya, Fitria (2012). Hubungan Antara Kematangan Karir dengan Motivasi Belajar pada Siswa Kelas X MAN Cibinong. http://publication.gunadarma.ac.id 